\title{
Genes and metabolic pathway of sarcoidosis: identification of key players and risk modifiers
}

Mihailo I. Stjepanovic ${ }^{1,2}$, Violeta Mihailovic-Vucinic ${ }^{1,2}$, Vesna Spasovski ${ }^{3}$, Jelena Milin-Lazovic ${ }^{2}$, Vesna Skodric-Trifunovic ${ }^{1,2}$, Sanja Stankovic ${ }^{4}$, Marina Andjelkovic ${ }^{3}$, Jovana Komazec ${ }^{3}$, Ana Momcilovic ${ }^{3}$, Milena Santric-Milicevic ${ }^{2,5}$, Sonja Pavlovic ${ }^{3}$

\author{
${ }^{1}$ Clinic of Pulmonology, Clinical Center of Serbia, Belgrade, Serbia \\ ${ }^{2}$ Medical Faculty, University of Belgrade, Belgrade, Serbia \\ ${ }^{3}$ Institute of Molecular Genetics and Genetic Engineering, University of Belgrade, \\ Belgrade, Serbia \\ ${ }^{4}$ Center for Medical Biochemistry, Clinical Center of Serbia, Belgrade, Serbia \\ ${ }^{5}$ Institute of Social Medicine, Faculty of Medicine, University of Belgrade, Belgrade, \\ Serbia
}

Submitted: 12 August 2018

Accepted: 17 October 2018

Arch Med Sci 2019; 15 (5): 1138-1146

DOI: https://doi.org/10.5114/aoms.2018.79682

Copyright (c) 2018 Termedia \& Banach

\begin{abstract}
Introduction: Sarcoidosis is a rare multisystem granulomatous disease with unknown etiology. The interplay of vitamin D deficiency and genetic polymorphisms in genes coding for the proteins relevant for metabolism of vitamin $D$ is an important, but unexplored area. The aim of this study was to investigate the association between single nucleotide polymorphisms (SNPs) in CYP2R1 (rs10741657), CYP27B1 (rs10877012), DBP (rs7041; rs4588), and $V D R$ ( $r$ 2228570) genes and sarcoidosis, as well as the association between these SNPs and 25(OH)D levels in sarcoidosis patients.

Material and methods: For that purpose we genotyped 86 sarcoidosis patients and 50 healthy controls using the PCR-RFLP method.

Results: Subjects carrying the CC genotype of CYP27B1 rs10877012 have 10 times lower odds of suffering from sarcoidosis. Moreover, DBP rs4588 AA genotype was shown to be a susceptibility factor, where carriers of this genotype had eight times higher odds for developing sarcoidosis. In addition, the A allele of the DBP gene (rs4588) was associated with lower levels of 25(OH)D in sarcoidosis patients.

Conclusions: These results suggest that patients with vitamin D deficiency should be regularly tested for genetic modifiers that are related to sarcoidosis in order to prevent development of serious forms of sarcoidosis.
\end{abstract}

Key words: single nucleotide polymorphisms, CYP27B1, VDR, DBP, CYP2R1, 25(OH)D.

\section{Introduction}

Sarcoidosis is a multisystem granulomatous disease characterized by noncaseating granulomas predominantly infiltrating the lungs, lymph nodes and skin [1].

This disease predominantly affects individuals between the age of 20 and 60, with an incidence ranging from 5-40 cases per 100,000 people in a white population up to 3-4 times higher in African Americans, with the lowest incidence recorded in Japan $[2,3]$. A significant proportion of

\author{
Corresponding author: \\ Mihailo I. Stjepanovic PhD \\ Clinic of Pulmonology \\ Clinical Center of Serbia \\ Koste Todorovica 26 \\ 11000 Belgrade, Serbia \\ Phone: +38 1668300074 \\ E-mail: mihailostjepanovic@ \\ gmail.com
}


patients suffering from sarcoidosis resolve spontaneously, resulting in a relatively low mortality rate, ranging from $1 \%$ to $5 \%$ depending on the severity of disease, location, age, ethnicity, and gender [4]. Nevertheless, a small number of patients develop a chronic or progressive disease with a fatal outcome, mainly due to respiratory or cardiac involvement [4]. The cause of sarcoidosis remains unknown, but considering that the affected organs represent entry points for immunologically active factors, it is believed that disease development requires exposure to environmental antigens, which acts as a trigger in a susceptible host.

Sarcoidosis is more common and occurs in a more serious form in darkly pigmented individuals living in regions with a higher incidence of vitamin D deficiency, such as the African-American population in the Southern United States of America [5-7]. This relationship was first brought to the attention of the scientific community more than 70 years ago, when hypercalcemia, which would worsen in patients consuming a vitamin D rich diet, was underlined as a feature of sarcoidosis, and the relation between vitamin $D$ and calcium abnormalities was hypothesized [8]. Two decades later, a group of authors proposed that the hormone causing this form of vitamin D intoxication is produced at an extra renal site, and another 30 years later calcitriol $(1,25(\mathrm{OH}) 2 \mathrm{D})$, produced by macrophages, was identified as the cause of hypercalcemia $[9,10]$.

Hypovitaminosis D has been identified as a risk factor for the development of active tuberculosis, and may also play a role in the pathogenesis of sarcoidosis.

Several studies report symptomatic osteomalacia with bone pain, as well as the sensation of fatigue and exhaustion, in sarcoidosis patients $[7,11,12]$. Most of these patients have had normal serum levels of calcitriol with low levels of inactive vitamin $25(\mathrm{OH}) \mathrm{D}[13,14]$. Sarcoid granulomas represent sites of autonomous conversion of vitamin $25(\mathrm{OH}) \mathrm{D}$ to vitamin $1,25(\mathrm{OH})_{2} \mathrm{D}$, and the level of calcitriol, which downregulates dendritic cells blocking the immune response, has been positively associated with the disease activity [15, 16]. Another proposed step in the pathogenesis of sarcoidosis linked to vitamin $D$ is the formation of noncaseating granulomas instead of caseating granulomas formed in tuberculosis, as a result of a defect in innate immunity [17].

The interplay of a relevant exposure, vitamin D deficiency and a susceptible host in the development of sarcoidosis has underlined a role of genetic polymorphisms in the pathogenesis of this disease [1]. It is believed that sarcoidosis, in its complexity, is influenced by numerous genes involved in vitamin D metabolic and signaling path- ways. Among them, proteins encoded by $C Y P 2 R 1$, $D B P, C Y P 27 B 1$, and $V D R$ genes play a significant role in metabolism of vitamin $D$ and conversion from the inactive to its active form. The CYP $2 R 1$ gene, together with CYP3A4 and CYP27A1 genes, encodes the 25-hydroxylating cytochrome P450 enzymes; vitamin $\mathrm{D}$ binding protein gene $(D B P)$ encodes the principle vitamin $D$ transport protein; CYP27B1 encodes the cytochrome P450 enzyme which $1 \alpha$-hydroxylates $25(\mathrm{OH}) \mathrm{D}$ to form $1,25(\mathrm{OH})_{2} \mathrm{D}$. Finally, the VDR gene encodes the vitamin $\mathrm{D}$ receptor which binds $1,25(\mathrm{OH})_{2} \mathrm{D}$ and forms a heterodimer with the retinoid $X$ receptor to mediate the biological actions of vitamin D [18].

The aim of this study was to investigate the association between single nucleotide polymorphisms (SNPs) in CYP2R1 (rs10741657), CYP27B1 (rs10877012), DBP (rs7041; rs4588), and VDR (rs2228570) genes and sarcoidosis, as well as the association between these SNPs and $25(\mathrm{OH}) \mathrm{D}$ levels in sarcoidosis patients.

\section{Material and methods}

We conducted a case-control study which included 86 patients with a diagnosis of sarcoidosis (cases) and 50 healthy subjects (controls). All patients were recruited from January 2015 until December 2016 at the University Clinic for Pulmonary Diseases, Clinical Centre of Serbia, Belgrade. On the day when blood samples for vitamin 25(OH)D analyses and genotyping were obtained, a detailed history of the disease course and duration were recorded.

All patients participating in this study were informed about the study requirements and aims, and signed the informed consent form. The study was approved by the Ethics Committee of the Clinical Center of Serbia, Belgrade, and the research was carried out in compliance with the Helsinki Declaration.

\section{Patients and controls}

For sarcoidosis patients, the inclusion criteria were a diagnosis of sarcoidosis confirmed by a detailed history of signs and symptoms, a chest X-ray, lung function tests, and a biopsy. All cases were suffering from sarcoidosis, defined as the form of the disease with both symptoms and signs of sarcoidosis activity and parameters of the activity present for more than 2 years. Controls were healthy subjects who agreed to participate in this study and for their collaboration received a detailed report on their blood analyses. Exclusion criteria for cases and controls were the same and included any history of diabetes mellitus, ischemic heart disease, chronic renal failure, jaundice or seropositivity for hepatitis B surface antigen, hepatitis $C$ virus or human immunodeficiency virus. 
M.I. Stjepanovic, V. Mihailovic-Vucinic, V. Spasovski, J. Milin-Lazovic, V. Skodric-Trifunovic, S. Stankovic, M. Andjelkovic, J. Komazec, A. Momcilovic, M. Santric-Milicevic, S. Pavlovic

Five $\mathrm{ml}$ of blood was drawn from the median cubital vein from cases and controls. Two $\mathrm{ml}$ were transferred into vials containing EDTA and frozen at $-20^{\circ} \mathrm{C}$ for subsequent DNA extraction, and $3 \mathrm{ml}$ were added to serum vials and sent to the laboratory within $2 \mathrm{~h}$ of collection, where serum was isolated from clotted blood by centrifugation and stored at $-20^{\circ} \mathrm{C}$ for subsequent determination of 25(OH)D concentration.

\section{Serum 25(OH)D analysis}

The adequacy of vitamin D intake is commonly evaluated by measuring the levels of vitamin $25(\mathrm{OH}) \mathrm{D}$, which is the major circulating form of vitamin $\mathrm{D}$ and is considered the best available clinical indicator of vitamin D status $[19,20]$. Although $1,25(\mathrm{OH}) 2 \mathrm{D}$ (calcitriol) is the active metabolite, only a tiny fraction of the $25(\mathrm{OH}) \mathrm{D}$ is converted to it, and it does not reflect the body stores of vitamin D. In addition, it has a much shorter half-life than $25(\mathrm{OH}) \mathrm{D}$, and normal or elevated levels of this metabolite are present even in patients with a vitamin $D$ deficiency $[21,22]$.

Vitamin D [25(OH)D] was measured at the Biochemical Laboratory of the Clinical Center of Serbia, Belgrade using the Elecsys Vitamin D total test. The test is based on the electro-chemo-luminescence method (ECLIA). The commercial reagents used were produced by Roche Diagnostics-Elecsys Vita min D total (REF 05894913190), Roche Diagnostics GmbH, Mannheim, Germany.

Following the reference values, serum vitamin 25(OH)D levels were defined as:

a) severe deficiency: a serum level of vitamin $25(\mathrm{OH}) \mathrm{D}<10 \mathrm{mg} / \mathrm{l}$

b) insufficiency: a serum level of vitamin $25(\mathrm{OH}) \mathrm{D}$ 10-30 mg/l;

c) sufficient: a serum level of vitamin $25(\mathrm{OH}) \mathrm{D}$ $>30 \mathrm{mg} / \mathrm{l}$

d) toxicity: a serum level of vitamin $25(\mathrm{OH}) \mathrm{D}$ $>100 \mathrm{mg} / \mathrm{l}$.

\section{Genotyping}

Genetic analysis was performed in the Laboratory for Molecular Biomedicine, Institute of Molecular Genetics and Genetic Engineering, University of Belgrade, Serbia. Genomic DNA was isolated from whole peripheral blood with the QIAamp DNA Mini Kit (Qiagen GmbH, Hilden, Germany), and stored at $-20^{\circ} \mathrm{C}$ until analysis. The detection of gene variants of CYP2R1, CYP27B1, DBP and $V D R$ genes was performed using the PCR-RFLP method. Primer sequences and PCR-RFLP conditions are given in Supporting information (Table I).

\section{Sample size and statistical analysis}

Continuous variables are presented as means with standard deviations or median with 25 and 75 percentiles, depending on the normality of their distribution, while categorical variables are presented as the number and percentage of cases. For continuous variables the distribution was tested using mathematical and graphical methods. Hardy-Weinberg equilibrium (HWE) was tested both for sarcoidosis patients and the control group.

The association between host genotype and sarcoidosis was assessed by univariate logistic regression, with adjustment for age. Results are expressed as odds ratios (OR) with 95\% confidence intervals $(\mathrm{Cl})$. The dominant model implies comparisons of homozygous genotypes for the major allele versus the group homozygous for the minor allele plus heterozygous genotype. The recessive model implies comparisons of recessive genotypes against heterozygous plus dominant homozygous. Associations between studied genes and 25(OH)D levels were assessed by the $\chi^{2}$ (categories of vita$\min \mathrm{D}:\langle 10 ; 10-30 ;>30 \mathrm{mg} / \mathrm{l})$ test and Mann-Whitney test (continuous values of vitamin D). All tests were two-tailed. The level of significance was set at 0.05 . Statistical analysis was performed

Table I. Sequences used for genotyping of CYP2R1, CYP27B 1, DBP and VDR genes

\begin{tabular}{|c|c|c|c|c|c|}
\hline Variable & Forward & Reverse & $\begin{array}{c}\text { Anneal- } \\
\text { ing tem- } \\
\text { perature } \\
{\left[{ }^{\circ} \mathrm{C}\right]}\end{array}$ & $\begin{array}{c}\text { PCR } \\
\text { product } \\
\text { size } \\
\text { [bp] }\end{array}$ & $\begin{array}{l}\text { Restriction } \\
\text { enzyme }\end{array}$ \\
\hline $\begin{array}{l}\text { CYP2R1 } \\
\text { rs10741657 }\end{array}$ & GGGAAGAGCAATGACATGGA & GCCCTGGAAGACTCATTTTG & 56 & 287 & Mnll \\
\hline $\begin{array}{l}\text { CYP27B1 } \\
\text { rs10877012 }\end{array}$ & GTGTTCCCTAAGTGTTGTCTC & GCTGACTCGGTCTCCTCTG & 56 & 666 & Tfil \\
\hline $\begin{array}{l}\text { DBP } \\
\text { rs7041; } \\
\text { rs4588 }\end{array}$ & AAATAATGAGCAAATGAAAGAAGAC & CAATAACAGCAAAGAAATGAGTAGA & 57 & 483 & $\begin{array}{c}\text { rs7041/ } \\
\text { Haelll } \\
\text { rs4588/ Styl }\end{array}$ \\
\hline $\begin{array}{l}\text { VDR } \\
\text { rs2228570 }\end{array}$ & AGCTGGCCCTGGCACTGACTCTGGCT & ATGGAAACACCTGCTTCTTCTCCCTC & 57 & 266 & Fokl \\
\hline
\end{tabular}

Validation of PCR-RFLP method was conducted using direct sequencing method, for randomly selected samples. 
using the IBM SPSS Statistics for Windows, Version 21.0. Armonk, NY: IBM Corp.

\section{Results}

\section{General characteristics of subjects who participated in the study}

Our study included a total of 136 subjects, of whom 86 were patients suffering from sarcoidosis (cases), and 50 were healthy controls. Sarcoidosis patients had a mean age of $48.7 \pm 10.2$ years, ranging from 27 up to 66 years, while the mean age in the control group was $39.2 \pm 11.3$ (ranging from 15-83), and this difference was statistically significant $(p<0.001)$. The sarcoidosis group consisted of 22 (25.6\%) men and 64 (74.4\%) women, compared to the control group which consisted of
19 (38\%) men and 31 (62\%) women. This difference was not statistically significant $(p=0.128)$. The average duration of the disease was $5.9 \pm 5.2$ years, with a median of 4 (range: 2-9 years). Twenty-seven (31.4\%) patients suffered from the acute form of sarcoidosis, while the chronic form was evident in 59 (68.6\%) patients. Demographic and clinical characteristics of sarcoidosis patients and healthy individuals who participated in this study are shown in Table II.

\section{Genotypes and sarcoidosis}

All genotype distributions were in Hardy-Weinberg equilibrium for all studied polymorphisms.

In order to analyze the association between certain genotypes and the risk of sarcoidosis, we used dominant and recessive genetic models.

Table II. Demographic, clinical and serological characteristics of sarcoidosis patients and healthy controls

\begin{tabular}{|c|c|c|c|}
\hline Parameter & & Sarcoidosis patients & Healthy individuals \\
\hline \multicolumn{4}{|l|}{ Demographic data: } \\
\hline Number & & 86 & 50 \\
\hline Age & Mean \pm SD & $48.7 \pm 10.2$ & $39.2 \pm 11.3$ \\
\hline \multirow[t]{2}{*}{ Sex distribution } & Women & $64(74.4 \%)$ & $31(62.0 \%)$ \\
\hline & Men & $22(25.6 \%)$ & $19(38.0 \%)$ \\
\hline \multicolumn{4}{|l|}{ Clinical parameters: } \\
\hline \multirow[t]{2}{*}{ Disease activity*** } & Acute & $27(31.4 \%)$ & \\
\hline & Chronic & $59(68.6 \%)$ & \\
\hline \multirow[t]{11}{*}{ Organ involved } & Lung & $84(97.7 \%)$ & \\
\hline & CNS & $14(16.3 \%)$ & \\
\hline & Skin & $4(4.7 \%)$ & \\
\hline & Eye & $8(9.3 \%)$ & \\
\hline & Liver & $1(1.2 \%)$ & \\
\hline & Spleen & $3(3.5 \%)$ & \\
\hline & Lymph node & $7(8.1 \%)$ & \\
\hline & Bone & $2(2.3 \%)$ & \\
\hline & Stomach & $1(1.2 \%)$ & \\
\hline & Parotid gland & $1(1.2 \%)$ & \\
\hline & Bone marrow & $1(1.2 \%)$ & \\
\hline \multirow[t]{4}{*}{ Ro stage } & 0 & $24(27.9 \%)$ & \\
\hline & 1 & $30(34.9 \%)$ & \\
\hline & 2 & $28(32.6 \%)$ & \\
\hline & 3 & $4(4.7 \%)$ & \\
\hline \multirow[t]{3}{*}{ Vitamin D status [mg/l] } & $<10$ & $38(44 \%)$ & \\
\hline & $10-30$ & $43(50 \%)$ & \\
\hline & $>30$ & $5(5.8 \%)$ & \\
\hline \multirow[t]{4}{*}{ Therapy } & Prednisone & $57(66.3 \%)$ & \\
\hline & Methotrexate & $4(4.7 \%)$ & \\
\hline & Prednisone + methotrexate & $2(2.3 \%)$ & \\
\hline & Without therapy & $23(26.7 \%)$ & \\
\hline
\end{tabular}


M.I. Stjepanovic, V. Mihailovic-Vucinic, V. Spasovski, J. Milin-Lazovic, V. Skodric-Trifunovic, S. Stankovic, M. Andjelkovic, J. Komazec, A. Momcilovic, M. Santric-Milicevic, S. Pavlovic

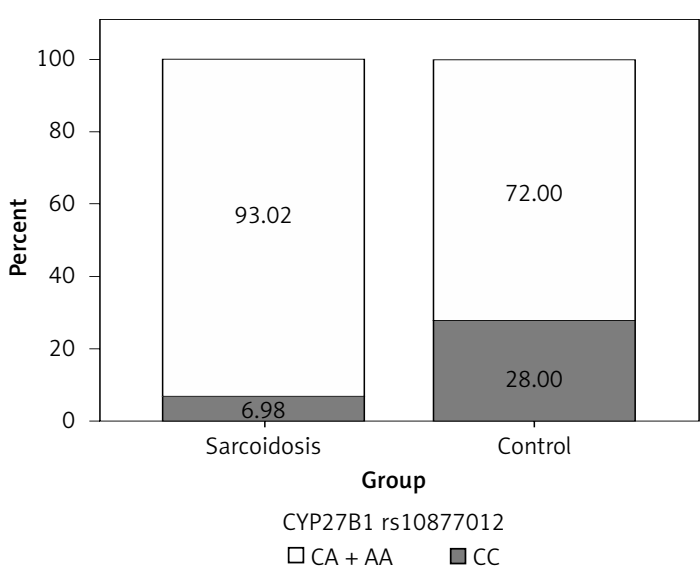

Figure 1. Distribution of $C C$ vs. $C A+A A$ genotypes of CYP27B1 rs10877012 among sarcoidosis patients and controls

Genotype CC (compared to CA + AA) of CYP27B1 rs10877012 was more frequent in the control group than in sarcoidosis patients, and this difference was statistically significant (Figure 1). Persons carrying this genotype had almost 10 times lower odds of suffering from sarcoidosis $(\mathrm{OR}=$ $0.116,95 \%$ Cl: 0.034-0.394, $p=0.001$ ) (Table III). This result shows that the CC genotype is a significant protector against sarcoidosis. In addition, genotype $\mathrm{AA}$ (compared to $\mathrm{CA}+\mathrm{CC}$ ) of the $D B P$ rs4588 gene was shown to be a significant predictor, increasing the odds of suffering from sarcoidosis eight times $(\mathrm{OR}=8.856,95 \% \mathrm{Cl}: 1.006-$ 77.953, $p=0.049$ ) (Table III, Figure 2 ).

\section{Genotypes and serum 25(OH)D levels}

Median serum level of vitamin D in our cohort of sarcoidosis patients was $10.8 \mathrm{mg} / \mathrm{l}$, where $44 \%$ of patients had a severe deficiency (a serum level of vitamin $25(\mathrm{OH}) \mathrm{D}<10 \mathrm{mg} / \mathrm{l}$ ) (Table II). We next wanted to establish the correlation between certain genotypes and serum vitamin $D$ level in sarcoidosis patients. We found that patients carrying the CA plus AA genotypes of DBP rs4588 had a lower median level of serum 25(OH)D (9.8 mg/l) compared to carriers of the CC genotype (12.3 $\mathrm{mg} / \mathrm{l})$ (Table IV). This difference was statistically significant $(p=0.046)$ (Table V, Figure 3). Moreover, carriers of AA genotype showed the lowest median levels of vitamin D of $5.7 \mathrm{mg} / \mathrm{l}$ (Table IV), which implies that allele $A$ is a predisposing factor for a low vitamin D level.

\section{Discussion}

Sarcoidosis is probably caused by the influence of specific environmental factors on the immune

Table III. Genotype distributions and summarized results of association study among sarcoidosis patients and controls

\begin{tabular}{|c|c|c|c|c|c|}
\hline Gene variant & Genotype & $\begin{array}{l}\text { Patients } \\
(n=86)\end{array}$ & $\begin{array}{l}\text { Controls } \\
(n=50)\end{array}$ & OR $(95 \% \mathrm{Cl})$ & $P$-value* \\
\hline \multirow[t]{3}{*}{ VDR rs 2228570} & CC & 39 & 23 & \multirow[t]{3}{*}{$0.922(0.428-1.987)$} & \multirow[t]{3}{*}{0.837} \\
\hline & СТ & 34 & 25 & & \\
\hline & TT & 13 & 2 & & \\
\hline \multicolumn{6}{|l|}{$C C$ vs. $C T+T T$} \\
\hline \multirow{3}{*}{$\begin{array}{l}\text { CYP27B1 } \\
\text { rs10877012 }\end{array}$} & CC & 6 & 14 & \multirow[t]{3}{*}{$0.116(0.034-0.394)$} & \multirow[t]{3}{*}{0.001} \\
\hline & CA & 39 & 19 & & \\
\hline & AA & 41 & 17 & & \\
\hline \multicolumn{6}{|l|}{$C C$ vs. $C A+A A$} \\
\hline \multirow{3}{*}{$\begin{array}{l}D B P \\
\text { rs7041 }\end{array}$} & TT & 18 & 6 & \multirow[t]{3}{*}{$1.763(0.597-5.204)$} & \multirow[t]{3}{*}{0.304} \\
\hline & TG & 39 & 29 & & \\
\hline & GG & 29 & 15 & & \\
\hline \multicolumn{6}{|l|}{$T T$ vs. $T G+G G$} \\
\hline \multirow{3}{*}{$\begin{array}{l}D B P \\
\text { rs4588 }\end{array}$} & $\mathrm{CC}$ & 42 & 25 & \multirow[t]{3}{*}{$8.856(1.006-77.953)$} & \multirow[t]{3}{*}{0.049} \\
\hline & CA & 34 & 24 & & \\
\hline & AA & 10 & 1 & & \\
\hline \multicolumn{6}{|l|}{$A A$ vs. $C A+C C$} \\
\hline \multirow[t]{3}{*}{ CYP2R1 rs 10741657} & GG & 34 & 28 & \multirow[t]{3}{*}{$0.542(0.251-1.170)$} & \multirow[t]{3}{*}{0.119} \\
\hline & GA & 42 & 18 & & \\
\hline & $\mathrm{AA}$ & 10 & 4 & & \\
\hline$G G$ vs. $G A+A A$ & & & & & \\
\hline
\end{tabular}


system of genetically predisposed individuals [23]. This study examined the associations between SNPs of the genes encoding key players in the vitamin D metabolic pathway and sarcoidosis, and explored their relationship to vitamin D levels in sarcoidosis patients. Although the association between vitamin $\mathrm{D}$ and sarcoidosis, as well as other pulmonary diseases, has been studied for decades, this is one of the first studies designed to explore the role of polymorphisms in genes CYP2R1, CYP27B1, DBP, and VDR of the vitamin D metabolic pathway in sarcoidosis patients. This was a relatively large study, considering that the incidence of sarcoidosis in Serbia (population $\sim 7$ million) is $16-20$ per 100,000 people [24], and is similar to that of countries at a similar latitude and skin color [2]. The main limitation of this study is the fact that sarcoidosis patients were older than the controls, and this difference was statistically significant. For that reason, all statistical calculations included adjustment for age.

Vitamin $D 1 \alpha$-hydroxylase is the product of the CYP27B1 gene, and this product catalyzes the synthesis of $1,25(\mathrm{OH})_{2} \mathrm{D}$, which is the active form of vitamin $D$ which binds to the vitamin $D$ receptor (VDR). There are some contradictory data $[25,26]$ available on the role of the CYP27B1-1260 promoter polymorphism rs10877012 which was studied in this paper. While Lange et al. suggested that this polymorphism could influence serum concentrations of $1,25(\mathrm{OH})_{2} \mathrm{D}$, Kitanaka et al. were unable to

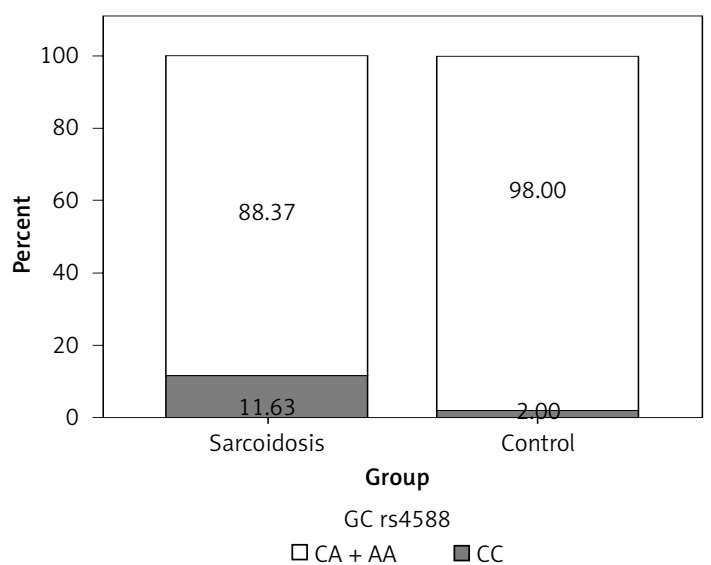

Figure 2. Distribution of AA vs. CA + CC genotypes of $D B P$ rs4588 among sarcoidosis patients and controls

confirm this relationship in Japanese children [25, 26]. In our study, the carriers of CA and AA genotypes of this gene were associated with 9 times higher odds of suffering from sarcoidosis. The dominant CC genotype had a protective effect, lowering the odds for sarcoidosis significantly. In sarcoidosis it is believed that the macrophages convert $25(\mathrm{OH}) \mathrm{D}$ to $1,25(\mathrm{OH})_{2} \mathrm{D}$, thus decreasing the vitamin $\mathrm{D}$ serum levels, with the product of this gene playing a key role $[27,28]$. Since our results showed no significant association between the CYP27B1 gene and $25(\mathrm{OH}) \mathrm{D}$ levels in sarcoidosis patients, we believe that increased expression, rather than poly-

Table IV. Level of vitamin D depending on genotypes in sarcoidosis patients

\begin{tabular}{|c|c|c|c|c|c|}
\hline \multirow[t]{2}{*}{ Genotype } & & \multicolumn{4}{|c|}{ Serum vitamin $25(\mathrm{OH})$ D level } \\
\hline & & Median & Percentile 25 & Percentile 75 & No. of patients \\
\hline \multirow[t]{3}{*}{ VDR rs2228570 } & $\mathrm{TT}$ & 9.3 & 5.5 & 11.8 & 13 \\
\hline & $\mathrm{CT}$ & 11.1 & 8.2 & 17.0 & 34 \\
\hline & $\mathrm{CC}$ & 11.6 & 6.3 & 25.2 & 39 \\
\hline \multirow{3}{*}{$\begin{array}{l}\text { CYP27B1 } \\
\text { rs10877012 }\end{array}$} & $\mathrm{CC}$ & 9.2 & 5.1 & 16.5 & 6 \\
\hline & CA & 10.8 & 8.0 & 18.0 & 39 \\
\hline & AA & 11.2 & 5.9 & 17.6 & 41 \\
\hline \multirow{3}{*}{$\begin{array}{l}\text { DBP } \\
\text { rs7041 }\end{array}$} & $\mathrm{TT}$ & 9.8 & 4.0 & 20.7 & 18 \\
\hline & TG & 10.0 & 5.8 & 15.9 & 39 \\
\hline & GG & 12.8 & 8.5 & 21.3 & 29 \\
\hline \multirow{3}{*}{$\begin{array}{l}D B P \\
\text { rs4588 }\end{array}$} & AA & 5.7 & 4.0 & 16.0 & 10 \\
\hline & CA & 10.0 & 5.8 & 15.6 & 34 \\
\hline & $\mathrm{CC}$ & 12.3 & 8.0 & 21.6 & 42 \\
\hline \multirow{3}{*}{$\begin{array}{l}\text { CYP2R1 } \\
\text { rs10741657 }\end{array}$} & GG & 10.6 & 7.0 & 17.0 & 34 \\
\hline & GA & 11.2 & 5.9 & 18.0 & 42 \\
\hline & AA & 10.9 & 6.3 & 18.0 & 10 \\
\hline
\end{tabular}


M.I. Stjepanovic, V. Mihailovic-Vucinic, V. Spasovski, J. Milin-Lazovic, V. Skodric-Trifunovic, S. Stankovic, M. Andjelkovic, J. Komazec, A. Momcilovic, M. Santric-Milicevic, S. Pavlovic

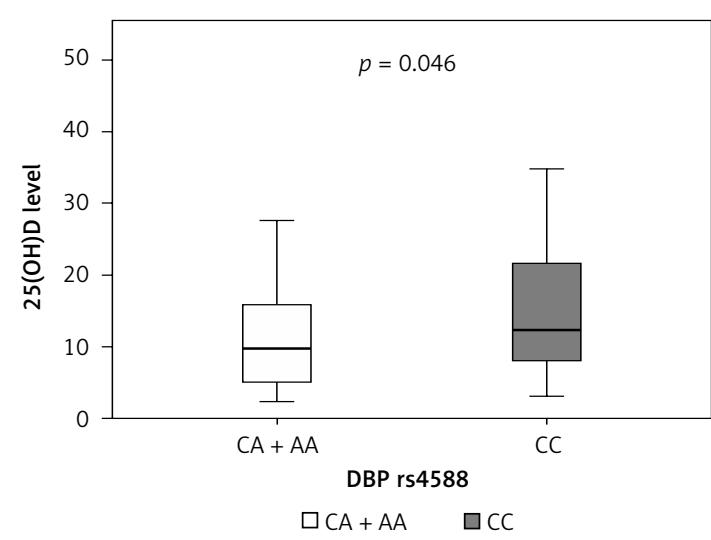

Figure 3. Comparison of 25(OH)D levels between carriers of CC vs. CA + AA genotypes of DBP rs 4588 The line inside the box represents the median value, and the box represents the first and third quartile of data

morphisms, could be a mechanism relevant for this phenomenon.

The vitamin $\mathrm{D}$ receptor, which binds $1,25(\mathrm{OH})_{2} \mathrm{D}$ and forms a heterodimer with the retinoid $X$ receptor and is crucial for vitamin $\mathrm{D}$ biological actions, is encoded by the VDR gene. In our study, we did not find that VDR rs2228570 is a susceptibility factor for sarcoidosis. We found that patients carrying the recessive $\mathrm{TT}$ genotype were more likely to have the lowest vitamin D levels, although this difference was not statistically significant (Table III). Other authors have reported minor alleles of the VDR gene to alter VDR function and expression, and individuals with VDR minor genotypes were more sensitive to vitamin $D$ administration and exhibited low calcium absorption [29-32]. Recent genome-wide association studies (GWAS) underline the contribution of vitamin D-related polymorphisms to variations in serum $25(\mathrm{OH}) \mathrm{D}$ levels $[33,34]$.
The vitamin $\mathrm{D}$ binding protein (DBP) is a serum $\alpha 2$-globulin which was initially named the "group-specific component" (Gc) in 1959 [35], and its functions include the transport of vitamin $\mathrm{D}$ and its metabolites, macrophage activation, actin scavenging, and fatty acid binding [36]. This protein has a half-life of less than 3 days, which is shorter compared to the half-life of $25(\mathrm{OH}) \mathrm{D}$ of several weeks, suggesting that the protein and its ligand are independently regulated [37-39]. DBP has a particularly high affinity to $25(\mathrm{OH}) \mathrm{D}$, which leaves less than $1 \%$ of it circulating free $[40,41]$. In our study, DBP rs4588 recessive genotype AA was shown to be a susceptibility factor for sarcoidosis. In addition, rs4588 was associated with $25(\mathrm{OH}) \mathrm{D}$ levels, with the recessive CC variant carriers having higher serum 25(OH)D levels than carriers of the CA and AA genotypes, thus confirming the results of previous studies [18]. We also found that carriers of AA genotype of $D B P$ rs4588 have the lowest levels of $25(\mathrm{OH}) \mathrm{D}$ in sarcoidosis patients.

CYP2R1 is known to encode the 25-hydroxylating cytochrome P-450 enzymes, and has been associated with variations in serum $25(\mathrm{OH}) \mathrm{D}$ levels [33, 42-45]. Nevertheless, in our study, it was not significantly associated with suffering from sarcoidosis, or with serum vitamin D levels in sarcoidosis patients.

Studying the interplay between sarcoidosis, vitamin D levels in the serum, and vitamin D pathway genes can provide valuable input for the understanding, as well as prevention and treatment, of this disease. Our results have underlined important associations between suffering from sarcoidosis and CYP27B1 rs10877012 and DBP rs4588 SNPs, as well as serum vitamin D levels and $D B P$ rs4588 SNPs, which might represent im-

Table V. Correlation of genotypes and level of vitamin D in sarcoidosis patients

\begin{tabular}{|c|c|c|c|c|c|}
\hline \multirow[t]{2}{*}{ Genotype } & & \multicolumn{3}{|c|}{$25(\mathrm{OH}) \mathrm{D}$ levels [mg/l] } & \multirow[t]{2}{*}{$P$-value ${ }^{a}$} \\
\hline & & Median & Percentile 25 & Percentile 75 & \\
\hline \multirow[t]{2}{*}{$V D R$} & $\mathrm{CC}+\mathrm{CT}$ & 11.5 & 7.0 & 20.7 & 0.110 \\
\hline & TT & 9.3 & 5.5 & 11.8 & \\
\hline \multirow[t]{2}{*}{ CYP27B1 } & $C A+C C$ & 10.8 & 8.0 & 18.0 & 0.869 \\
\hline & AA & 11.2 & 5.9 & 17.6 & \\
\hline \multirow[t]{2}{*}{ DBP rs7041 } & $\mathrm{TT}+\mathrm{TG}$ & 10.0 & 5.5 & 16.0 & 0.131 \\
\hline & GG & 12.8 & 8.5 & 21.3 & \\
\hline \multirow[t]{2}{*}{$D B P$ rs4588 } & $C A+A A$ & 9.8 & 5.1 & 15.8 & 0.046 \\
\hline & CC & 12.3 & 8.0 & 21.6 & \\
\hline \multirow[t]{2}{*}{ CYP2R1 } & $G G+G A$ & 10.8 & 6.6 & 17.8 & 0.803 \\
\hline & AA & 10.9 & 6.3 & 18.0 & \\
\hline
\end{tabular}

Median, first, and third quartile values of serum D3 levels in recessive genetic model of studied genes. ${ }^{a}$ Mann-Whitney $U$ test. 
portant aspects to consider in monitoring, measurement, and substitution in the treatment of patients with sarcoidosis in the future. In studies of the efficacy of vitamin $D$ supplementation in the general population, $D B P$ and $C Y P 2 R 1$ genes, which were associated with baseline $25(\mathrm{OH}) \mathrm{D}$ levels, did not modify the response to supplementation [46]. Contrarily, two other SNPS (CYP24A1 and VDR), which were not associated with baseline levels, did alter the response [46]. Fu et al. found that different DBP genotypes in healthy subjects may elicit different responses to the same vitamin D dose, although without proposing a specific genetic association model [47]. Despite the clear clinical benefits and effective reduction of the symptoms due to vitamin $D$ supplementation among different immunological conditions [48-50], treatment of sarcoidosis patients in this respect is not so clear. In sarcoidosis patients this problem is even more complicated due to calcium disorders, allowing supplementation and sunlight exposure only for patients with normal levels of serum or urine calcium [24]. Future studies of sarcoidosis and other vitamin $D$ associated diseases should focus their effort on better explaining these associations and exploring the influence of other factors related to vitamin $D$ related SNPS on the prevention, outcomes, and response to therapy.

In conclusion, there is enough evidence to support the essential role of vitamin D and its metabolic pathway genes in sarcoidosis. This study has underlined the CYP27B1 and DBP SNPs which were significantly associated with this disease and serum 25(OH)D levels in sarcoidosis patients for the first time. This study has improved our understanding of the role of genetic modifiers in the management of sarcoidosis, but its findings should be confirmed using a larger sample size in future studies.

\section{Acknowledgments}

This study was supported by the Serbian Ministry of Education and Science (grants no. III41004, 175018, 175046 and 175081).

\section{Conflict of interest}

The authors declare no conflict of interest.

\section{References}

1. Culver DA. Sarcoidosis. Immunol Allergy Clin North Am 2012; 32: 487-511.

2. Carmona EM, Kalra S, Ryu JH. Pulmonary sarcoidosis: diagnosis and treatment. Mayo Clin Proc 2016; 91: 946-54.

3. Iannuzzi MC, Rybicki BA, Teirstein AS. Sarcoidosis. N Engl J Med 2007; 357: 2153-65.

4. Gerke AK. Morbidity and mortality in sarcoidosis. Curr Opin Pulm Med 2014; 20: 472-8.
5. Benatar SR. Sarcoidosis in South Africa. A comparative study in Whites, Blacks and Coloureds. South African Med J 1977; 52: 602-6.

6. Rybicki BA, Major M, Popovich JJ, et al. Racial differences in sarcoidosis incidence: a 5 -year study in a health maintenance organization. Am J Epidemiol 1997; 145: 234-41.

7. Sharma OP. Vitamin D and sarcoidosis. Curr Opin Pulm Med 2010; 16: 487-8.

8. Harrell GT, Fisher S. Blood chemical changes in boeck's sarcoid with particular reference to protein, calcium and phosphatase values. J Clin Invest 1939; 18: 687-93.

9. Singer FR, Adams JS. Abnormal calcium homeostasis in sarcoidosis. N Engl J Med 1986; 315: 755-7.

10. Henneman PH, Dempsey EF, Carroll EL, Albright F. The cause of hypercalcuria in sarcoid and its treatment with cortisone and sodium phytate. J Clin Invest 1956; 35: 1229-42.

11. Sharma OP. Vitamin D, calcium, and sarcoidosis. Chest 1996; 109: 535-9.

12. Junaid K, Rehman A, Jolliffe DA, et al. Vitamin D deficiency associates with susceptibility to tuberculosis in Pakistan, but polymorphisms in VDR, DBP and CYP2R1 do not. BMC Pulm Med 2016; 16: 73.

13. Burke RR, Rybicki BA, Rao DS. Calcium and vitamin D in sarcoidosis: how to assess and manage. Semin Respir Crit Care Med 2010; 31: 474-84.

14. Sweiss NJ, Lower EE, Korsten P, et al. Bone health issues in sarcoidosis. Curr Rheumatol Rep 2011; 13: 265-72.

15. Ben-Zvi I, Aranow C, Mackay M, et al. The impact of vitamin $D$ on dendritic cell function in patients with systemic lupus erythematosus. PLoS One 2010; 5: e9193.

16. Hamada K, Nagai S, Tsutsumi T, Izumi T. Ionized calcium and 1,25-dihydroxyvitamin $\mathrm{D}$ concentration in serum of patients with sarcoidosis. Eur Respir J 1998; 11: 1015-20.

17. Richmond BW, Drake WP. Vitamin D, innate immunity, and sarcoidosis granulomatous inflammation: insights from mycobacterial research. Curr Opin Pulm Med 2010; 16: 461-4.

18. Jolliffe DA, Walton RT, Griffiths CJ, Martineau AR. Single nucleotide polymorphisms in the vitamin D pathway associating with circulating concentrations of vitamin $D$ metabolites and non-skeletal health outcomes: review of genetic association studies. J Steroid Biochem Mol Biol 2016; 164: 18-29.

19. Merlino LA, Curtis J, Mikuls TR, et al. Vitamin D intake is inversely associated with rheumatoid arthritis: results from the lowa Women's Health Study. Arthritis Rheum 2004; 50: 72-7.

20. Dawson-Hughes B, Mithal A, Bonjour JP, et al. IOF position statement: vitamin $\mathrm{D}$ recommendations for older adults. Osteoporos Int 2010; 21: 1151-4.

21. Kennel KA, Drake MT, Hurley DL. Vitamin D deficiency in adults: when to test and how to treat. Mayo Clin Proc 2010; 85: 752-8.

22. Thacher TD, Clarke BL. Vitamin D insufficiency. Mayo Clin Proc 2011; 86: 50-60.

23. Kieszko R, Krawczyk P, Powrózek T, et al. The impact of ACE gene polymorphism on the incidence and phenotype of sarcoidosis in rural and urban settings. Arch Med Sci 2016; 12: 1263-72.

24. Mihailović-Vučinić V, Ignjatović S, Dudvarski-llić A, et al. The role of vitamin $D$ in multisystem sarcoidosis. J Med Biochem 2012; 31: 339-46.

25. Lange CM, Bojunga J, Ramos-Lopez E, et al. Vitamin D deficiency and a CYP27B1-1260 promoter polymorphism are associated with chronic hepatitis $C$ and poor 
response to interferon-alfa based therapy. J Hepato 2011; 54: 887-93.

26. Kitanaka S, Isojima T, Takaki M, et al. Association of vitamin D-related gene polymorphisms with manifestation of vitamin D deficiency in children. Endocr J 2012; 59: 1007-14.

27. Holick MF. Vitamin D deficiency. N Engl J Med 2007; 357: 266-81.

28. Hewison M, Burke F, Evans KN, et al. Extra-renal 25-hydroxyvitamin D3-1alpha-hydroxylase in human health and disease. J Steroid Biochem Mol Biol 2007; 103: 316-21.

29. Martineau AR, Timms PM, Bothamley GH, et al. Highdose vitamin $\mathrm{D}(3)$ during intensive-phase antimicrobial treatment of pulmonary tuberculosis: a double-blind randomised controlled trial. Lancet 2011; 377: 242-50.

30. Wishart JM, Horowitz M, Need AG, et al. Relations between calcium intake, calcitriol, polymorphisms of the vitamin D receptor gene, and calcium absorption in premenopausal women. Am J Clin Nutr 1997; 65: 798-802

31. Ogunkolade BW, Boucher BJ, Prahl JM, et al. Vitamin D receptor (VDR) mRNA and VDR protein levels in relation to vitamin D status, insulin secretory capacity, and VDR genotype in Bangladeshi Asians. Diabetes 2002; 51: 2294-300.

32. Whitfield GK, Remus LS, Jurutka PW, et al. Functionally relevant polymorphisms in the human nuclear vitamin D receptor gene. Mol Cell Endocrinol 2001; 177: 145-59.

33. Wang TJ, Zhang F, Richards JB, et al. Common genetic determinants of vitamin D insufficiency: a genome-wide association study. Lancet 2010; 376: 180-8.

34. Ahn J, Yu K, Stolzenberg-Solomon R, et al. Genome-wide association study of circulating vitamin D levels. Hum Mol Genet 2010; 19: 2739-45.

35. Hirschfeld J. Immune-electrophoretic demonstration of qualitative differences in human sera and their relation to the haptoglobins. Acta Pathol Microbiol Scand 1959; 47: $160-8$

36. Speeckaert M, Huang G, Delanghe JR, Taes YEC. Biological and clinical aspects of the vitamin D binding protein (Gc-globulin) and its polymorphism. Clin Chim Acta 2006; 372: 33-42.

37. Gozdzik A, Zhu J, Wong BYL, et al. Association of vitamin $\mathrm{D}$ binding protein (VDBP) polymorphisms and serum $25(\mathrm{OH}) \mathrm{D}$ concentrations in a sample of young Canadian adults of different ancestry. J Steroid Biochem Mol Biol 2011; 127: 405-12.

38. Sinotte M, Diorio C, Bérubé S, et al. Genetic polymorphisms of the vitamin $\mathrm{D}$ binding protein and plasma concentrations of 25-hydroxyvitamin $D$ in premenopausal women. Am J Clin Nutr 2009; 89: 634-40.

39. Safadi FF, Thornton P, Magiera $\mathrm{H}$, et al. Osteopathy and resistance to vitamin $D$ toxicity in mice null for vitamin D binding protein. J Clin Invest 1999; 103: 239-51.

40. Rowling MJ, Kemmis CM, Taffany DA, Welsh J. Megalin-mediated endocytosis of vitamin D binding protein correlates with 25-hydroxycholecalciferol actions in human mammary cells. J Nutr 2006; 136: 2754-9.

41. Nykjaer A, Dragun D, Walther D, et al. An endocytic pathway essential for renal uptake and activation of the steroid 25-(OH) vitamin D3. Cell 1999; 96: 507-15.

42. Robien K, Butler LM, Wang R, et al. Genetic and environmental predictors of serum 25-hydroxyvitamin D concentrations among middle-aged and elderly Chinese in Singapore. Br J Nutr 2013; 109: 493-502.

43. Hassanein SI, Abu El Maaty MA, Sleem HM, Gad MZ. Triangular relationship between single nucleotide poly- morphisms in the CYP2R1 gene (rs10741657 and rs12794714), 25-hydroxyvitamin D levels, and coronary artery disease incidence. Biomarkers 2014; 19: 488-92.

44. Nissen J, Rasmussen LB, Ravn-Haren G, et al. Common variants in CYP2R1 and GC genes predict vitamin D concentrations in healthy Danish children. PLoS One 2014; 9: e89907.

45. Ye Z, Sharp SJ, Burgess S, et al. Association between circulating 25-hydroxyvitamin D and incident type 2 diabetes: a mendelian randomisation study. Lancet Diabetes Endocrinol 2015; 3: 35-42.

46. Barry EL, Rees JR, Peacock JL, et al. Genetic variants in CYP2R1, CYP24A1, and VDR modify the efficacy of vitamin D3 supplementation for increasing serum 25-hydroxyvitamin D levels in a randomized controlled trial. J Clin Endocrinol Metab 2014; 99: E2133-7.

47. Fu L, Yun F, Oczak M, et al. Common genetic variants of the vitamin $\mathrm{D}$ binding protein (DBP) predict differences in response of serum 25-hydroxyvitamin D [25(OH)D] to vitamin D supplementation. Clin Biochem 2009; 42: 1174-7.

48. Salahuddin N, Ali F, Hasan Z, Rao N, Aqeel M, Mahmood F. Vitamin D accelerates clinical recovery from tuberculosis: results of the SUCCINCT Study [Supplementary Cholecalciferol in recovery from tuberculosis] A randomized, placebo-controlled, clinical trial of vitamin D supplementation in patients with pulmonary tuberculosis'. BMC Infect Dis 2013; 13: 22.

49. Khadilkar VV, Khadilkar AV. Use of vitamin D in various disorders. Indian J Pediatr 2013; 80: 215-8.

50. Jerzyńska J, Stelmach W, Rychlik B, et al. Clinical and immunological effects of vitamin D supplementation during the pollen season in children with allergic rhinitis. Arch Med Sci 2018; 14: 122-31. 